\title{
Kdo nejvíce přivádí mládež ke sportu?
}

\section{Who brings the most youth to sport?}

\author{
${ }^{1}$ Zdeněk Valjent, ${ }^{2}$ Libor Flemr \\ ${ }^{1}$ Ústav tělesné výchovy a sportu, České vysoké učení technické v Praze \\ ${ }^{2}$ Fakulta tělesné výchovy a sportu Univerzity Karlovy v Praze
}

\begin{abstract}
Abstrakt
Studie zkoumá na vzorku 1221 studentů ČVUT, z toho 947 studentů a 274 studentek ve věku 20-28 let, jakou mèrou se v jejich životě podíleli na formování jejich osobnosti se zaměrením na výchovu k pravidelné pohybové činnosti vybrané osoby a instituce.

Výsledky potvrzují, že vybrané indikátory se podílí na výchově mládeže ve smyslu kladného ovlivnèní ke sportovní činnosti rozdílnou mèrou. U chlapců se o to nejvice přičiňují kamarádi a spolužáci (průmèr na 7 bodové Likertově škále 5,37), těsně sledováni rodinou $(5,15)$ a také učiteli tělesné výchovy na vysoké škole $(4,79)$. Na děvčata má nejvètší kladný vliv jejich rodina $(5,34)$, kamarádky a spolužačky $(5,26)$ a také jejich partneři $(5,16)$. Nejméně na ně v tomto smyslu výchovně pưsobí učitelé TV na SŠ $(4,31$ u chlapců; resp. 4,04 u děvčat), naši sportovní reprezentanti (4,30; resp. 4,21) a učitelé TV na ZŠ (4,10; resp. u děvčat dokonce 3,90, což je jediná záporná hodnota ze všech indikátorů).
\end{abstract}

\begin{abstract}
The implementation of regular physical activity and sport of youth depends on genetic predisposition influenced by many factors. The study examines on sample of 1221 students of ČVUT, including 947 boys and 274 girls in age 20-28 years.

The results confirm that the selected indicators are involved in education of youth within the meaning of positive influence to sports activities by different degrees. Friends and schoolmates do one's best (average of 7-point Likert scale 5,37) about it at boys, closely watched by family $(5,15)$ and teachers of physical education at university $(4,79)$. The family of girls have the largest positive influence $(5,34)$, friends and schoolmates $(5,26)$ and also their boyfriends $(5,16)$. Teachers of physical education from high schools have the least influence (4,31 at boys, respectively 4,04 at girls), our national representative sport teams (4,30, respectively 4,21) and teachers of physical education at elementary schools $(4,10$, respectively even 3,90 at girls - the only negative value of all indicators).
\end{abstract}

Klíčová slova: $\quad$ mládež, motivace, sport, technická univerzita

Key words: $\quad$ youth, motivation, sport, technical university

\section{ÚVOD}

Dnes jsme u nás v ČR i v širším mezinárodním měřítku svědky výzkumně prokazatelné nedostatečné orientace dětí a mládeže na pohybové a sportovní aktivity. Na přelomu tisíciletí kolem $40 \%$ dětí a mládeže trpělo především $\mathrm{v}$ důsledku sedavého způsobu života nějakým typem zdravotního oslabení (Bouchard et al., 1988; Baranovski et al., 1992; Sekot, 2004). Podle Ferrona et al. (1999) nesportující adolescenti trpí oproti sportujícím o mnoho více zdravotními, somatickými a psychickými problémy, které se pak odrážejí i v jejich chování a duševním životě. U sportující mládeže se nachází větší důvěra ve své zdraví, estetičtější tělesný vzhled, méně pokusů o sebevraždu, menší užití tabákových výrobků, vína a marihuany.

Situace mezi dětmi a mládeží je alarmující, protože ke snižování pohybové aktivity dochází podle mnoha studií již mezi 10-12 lety (Brodersen et al., 2007; Seefeldt et al., 1992), podle některých autorů o něco později (např. Brockman et al., 2009; Brown, 1985). 
Výchovným a osvětovým cílem společnosti je proto přivést co největší množství mládeže a posléze i dospělých občanů k pravidelné pohybové činnosti, tzv. aktivnímu životnímu stylu. Ten chápeme jako interakci mezi jedincem a okolím a charakterizujeme jako životní styl závislý na vzájemné kladné kombinaci především těchto faktorů: zdravé výživě, pitném režimu, rizikových faktorech (kouření, pití alkoholu, drogy), konzumu médií (TV, počítače) a pohybové aktivitě. Mluví se zde o pravidle $3 \mathrm{P}$ : Přiměřenosti v př́ijmu živin a energie, Pravidelnosti pohybové aktivity a Prevenci v předcházení nezdravým stravovacím a životním návykům (Bunc, 2008; Valjent, 2008).

Fyzická aktivita a sport je proto chápána primárně jako ochranný faktor proti stresu a depresím, stává se prostředkem k vyplňování volného času mládeže a jako prevence kriminality, užívání drog a společensky nežádoucích způsobů chování a jednání (Dishman, 1985; Koukal, 1996).

Většina informací z oblasti socializace sportem naznačuje, že participace dětí a mládeže na neformálních i organizovaných formách sportu je ovlivňována dostupností přiležitostí, podporou rodinných př́ślušníků a školy, kamarádů, názorových vůdců a životních vzorů, nejbližšś komunitou a konečně i vnímavostí potencionálního dětského účastníka sportovních aktivit (Coakley, 1987; Sekot, 2003).

$\mathrm{V}$ empirických výzkumech se dochází $\mathrm{k}$ závěrům, že především rodina je největší hnací silou ke sportování dětí a mládeže. Čím vyšší význam přisuzují rodiče sportu, tím silněji děti chápou sport jako hodnotnou atraktivní činnost. Zejména rodiče jsou těmi, kdo obdarovávají své děti sportovní výstrojí a výzbrojí. Právě rodiče učí své děti házet a chytat míč, učí je plavat, bruslit, lyžovat a jezdit na kole. Od rodičů se dozvídají, jak se zúčastnit závodu, soutěžit o ceny a dosahovat socializačně stimulativních cílů (Sekot, 2003).

Sigmund et al. (2008) došli podobně jako mnoho zahraničních autorů ve své studii k závěru, že pohybově aktivnější rodiče, otcové i matky, vychovávají pohybově aktivnější děti, zřetelněji u synů.

Teoretické úvahy podpořené řadou empirických výzkumů upozorňují ovšem na vyšší míru sportovní participace vyšších vrstev; mluví se tak o sportovní činnosti mládeže závislé na socioekonomickém statusu rodiny (Sekot, 2003). Sportování je častěji součástí životního stylu u vyšších vrstev (Skille, 2005; Warde, 2006). Význam zde mají nejen ekonomické nerovnosti (množství disponibilního př́ijmu), ale i kulturní odlišnosti lidí s různým postavením ve společnosti (Bourdieu, 1978; Collins, 2004; Špaček, 2008). Špačkova (2008) studie ukazuje na základě dat z náhodných souborů let 1984, 1991 a 2007, že přes určitý nárůst celkové míry sportovní participace v České republice zde přetrvávají značné rozdíly mezi různými sociálními vrstvami. Pokud rodiče a jejich celá rodina sami sportují, pak předávají tento prvek svého životní stylu i svým dětem.

Jak Sallis a Owen (1999) ve starší studii, tak i Brockman a kol. (2009) v nejnovější studii konstatují, že většina rodičů podporuje a motivuje své děti ke sportování. Faktorem, který ale rozděluje děti podle jejich socioekonomického statusu (dále SES), je vstupní cena do různých sportovních oddílů, náklady na sportovní vybavení a cestování. Tělesné aktivity mládeže patřící k vyššímu SES bývají organizovány ve sportovních klubech pod dohledem expertů a realizovány po škole a o víkendu. Sportování mládeže s nižším SES se děje nejvíce jako neřízená aktivní volná hra bez dozoru dospělých, např. jako aktivní hra v parku nebo v ulicích s kamarády. Mládež s vyšším SES má s pomocí rodiny vytvořeny lepší podmínky pro zapojení do fyzických aktivit než mládež s nižším SES (In: Flemr, Valjent; 2010).

Seabra (2008) zjistil, že dospívající mládež s vysokým SES se zabývá pravidelnou sportovní činností ze $71 \%$, mládež se středním SES z 59 \% a mládež s nízkým SES pouze z $50 \%$. To ale nejspíše ještě nemusí platit u mladších dětí do 9 let, nebot Sallis et al. (1992) zjistil u chlapců z neúplných rodin, že především díky méně častému dozoru nad sebou a při spoléhání se na vlastní dopravu naopak mají více pohybové aktivity než chlapci z úplných rodin. Staempfli (2009) také uvádí, že neřízená hra nabízí i některé výhody, např. častější řešení sociálních konfliktů, řízení rizik a rozvoj autonomie. Otázku zde také hraje i druh sportovní činnosti; např. trénovat tenis, krasobruslení a podobně finančně náročné sporty je pro chudší děti naprosto nemyslitelné (Baxter, Maffulli; 2003). 
Při hledání odpovědi na otázku, jestli má větší vliv na sportování dětí otec nebo matka, se výsledky studií liší. Davison et al. (2003) se domnívá, že matky se lépe starají o organizování sportu pro své dítě, otcové spíše slouží jako kladný příklad svým vlastním chováním. Lewko a Greendorfer (1988) preferují především větší vliv otců. Seabra (2008) ve své studii provedené u portugalské mládeže zjistil, že dcery se mnohem pravděpodobněji zapojí do sportu, pokud sportují i jejich matky. Podle Greendorfera (1992) je socializační efekt sourozenců na sport menší než rodičů.

Neméně vlivným faktorem pro zahájení a udržení fyzické aktivity mládeže jsou přátelé, kamarádi, spolužáci a udržované přátelství mezi nimi. Jago et al. (2009) rozlišuje u mládeže tř́i druhy vznikajících přátelství, která mezi nimi mohou působit jako stimul k pohybové aktivitě: mezi spolužáky ze školy, mezi kamarády z organizovaných aktivit a mezi dětmi přátel rodičů. Mezi chlapci je fyzická aktivita vnímána jako pozitivní atribut, u děvčat je to trochu složitější, u některých sociálních skupin je nízká fyzická aktivita dokonce vnímána jako žádoucí. Radost a požitek jsou nejdůležitějšími faktory, které udržují sportovní aktivity mezi přáteli.

Dále je vhodné upozornit na diference mezi pohlavími (např. Koivula, 2000; Sekot, 2008), které jsou již patrné ve vnímání dětí jejich rodiči (Kremer, Scully; 1998). Sociologové došli k závěru, že orientace na sportovní výkon u mládeže je umocňována prostředím soutěživého ducha moderní společnosti významněji u hochů než u dívek. Mění se přibývajícím časem a také v závislosti na míře př́ležitosti a povaze kontaktů s okolním světem (Coakley, 2001). Dívky sice nejsou od sportovních činností vysloveně zrazovány, ale jejich čas pro sportovní činnosti je školní a rodičovskou autoritou více usměrňován a kontrolován, než v případě chlapců. Tato forma "podmíněného povolení“ ovlivňuje vývoj sportovních dovedností mladých dívek; navíc může omezovat i povahu her a neformálních sportovních činností sdílených s přáteli v pozdějším věku. Chlapci nejsou zpravidla vystaveni tak silné autoritě dospělých. Do světa fyzických dovedností spojených se sportem pronikají obvykle již v mladém věku a s přibývajícími léty u nich kredit sportu roste jako nedílná součást dozrávání v muže (Sekot, 2003). Obecně lze konstatovat, že soutěžení a kompetitivní sport více přitahuje chlapce (McGinnis et al., 2003), společenské uznání je typičtější pro dívky (Greendorfer, Ewing; 1981). Davison a Schmalzová (2006) upozorňují, že nejsilněji ohroženou skupinou jsou obézní dívky, které nejsou vychovány s vědomím nutnosti věnovat se pravidelné pohybové činnosti.

Podle Rychteckého (2006) patř́ mezi potvrzené tendence účasti adolescentů (10-19 let) ve sportovních a pohybových aktivitách: větší inklinace chlapců k organizované formě sportu; vyšší účast v organizovaném sportu v městských sídlech; větší popularita neorganizovaných aktivit ve venkovských oblastech; větší přitažlivost komerčně orientovaných aktivit (taneční studia, fitness centra) pro dívky; větší obliba cvičení doma či s rodinnými př́slušníky u dívek.

Jestli se mládež podaří přivést ke sportu, záleží také na iniciativě pedagogů (zejména učitelů tělesné výchovy) především základních a středních škol. Právě ti mají nabídnout schůdnou cestu k plnohodnotnému a aktivnímu životnímu stylu (Koukal, 1996).

Vliv jednotlivých výchovných činitelů na pohybovou aktivitu se mění se stoupajícím věkem mládeže. Adolescenti mají různé důvody pro to, co dělají, a některé z nich se rychle mění. Patriksson (1994) uvádí, že při zapojení mládeže do sportu se většinou jedná o kombinaci více faktorů. Obecně se dá říci, že především vliv rodiny a učitelů v závislosti na čase klesá a vliv kamarádů a spolužáků stoupá (Davison, Jago; 2009; Seabra, 2008). Jakmile se děti blíží k adolescenci, jsou velice silně formovány vrstevnickými skupinami. Tyto skupiny mají silný vliv na jejich hodnotovou orientaci, postoje a chování, které může být ve vztahu ke sportovním aktivitám v rozporu s představami dospělých (Hogg, Abrams; 1988; Laušman, 1992; Jansa et al., 2005). V již zmíněné portugalské studii dospívající mládeže Seabra et al. (2008) zjistil, že více než 70 \% chlapců a dívek se účastnilo sportovních aktivit, pokud sportoval i otec, matka a sourozenci; $73 \%$ mladistvích sportovalo, když k tomu bylo ovlivněno svými vrstevníky; a $63 \%$ z nich sportovalo na základě ovlivnění svými učiteli tělesné výchovy. Vliv učitele TV byl sice stále pozitivní, ale překvapil s postupujícím věkem mládeže jeho oslabující vliv na úkor formování vědomí ze strany vrstevnické skupiny. 


\section{CÍL PRÁCE}

Předkládaná studie zkoumá míru ovlivnění mládeže při motivaci ke sportu několika vybranými indikátory. Dává si za cíl stanovit pořadí těchto indikátorů a také zjistit, jestli př̀i přivádění ke sportu ovlivňují chlapce a děvčata rozdílným způsobem.

\section{METODIKA}

\section{Charakteristika výzkumného souboru}

Hlavní výzkumný soubor tvořilo celkem 1221 studentů ČVUT. Z toho bylo 947 studentů (77,6\%) a 274 studentek (22,4\%) ve věku 20-28 let. Pocházeli ze všech krajů České republiky včetně Slovenska (3,7\%) a zahraničí $(0,4 \%)$, nejvíce samozřejmě z Prahy $(28,3 \%)$ a Středočeského kraje $(15,9 \%)$. Soubor je kvazireprezentativní, tj. reprezentuje základní soubor studentů vyšších ročníků ČVUT v logickém, nikoli však ve statistickém slova smyslu (Zich, 2005). Dostatečná velikost výběrového souboru nám dovoluje získané výsledky obezřetně zobecňovat na základní soubor - všechny studenty ČVUT (Blaikie, 2003; Hnilicová, 2004).

\section{Použité techniky}

Přesné znění všech otázek v dotazníku bylo dopracováno ve shodě s Lawshem (1975) a odsouhlaseno na ústních konzultacích se třemi sociologickými experty. V dotazníku jsme vymezili na Likertově sedmibodové škále kategorie, které jsou si zde navzájem rovnocenné co do síly výroku (Pecha, 2005).

Konečné otestování dotazníku jsem provedl pilotní studií na souboru 53 studentů. Tato skupina podstoupila test reliability metodou opakovaného měření (Chráska, 2007; Řehák, 1998) s výsledkem hodnoty Spearmanova koeficientu mezi 0,48- 0,85.

Empirický výzkum byl proveden neinvazivním deskriptivním zjištováním za použití kvantitativní diagnostické metody - dotazníkového šetření. Výzkum proběhl v květnu a červnu 2008 na studentech vyšších ročníků, kteří měli za sebou nejméně 2 ročníky studia.

Analýza dat byla provedena pomocí statistického programového systému SPSS verze 14.0. Při analýze kvantitativních dat jsem použil jako metody pro určení polohy a rozptýlení - průměr na škále (aritmetický průměr) a směrodatnou odchylku (Std.), nebot’ se v sociologických výzkumech běžně využívají (Sak, 2000, 2004; Zich, 2005). K určování rozdílů mezi studenty a studentkami v jednotlivých indikátorech jsem pro stanovení „věcné významnosti” (Blahuš, 2000; Soukup, Rabušic, 2007) použil „mediánové kategorie" obou souborů, což je kategorie, pro kterou kumulativní četnost je 0,5 nebo vyšší, když pro předchozí kategorii byla kumulativní četnost menší než 0,5 . Tato charakteristika je tedy pro hodnocené proměnné stř̌ední hodnotou (̌̌ezanková, 2007).

Hodnoty pro hodnocení věcné významnosti jsem předem stanovil na základě tvrzení Zicha (2004, s. 80) takto:

Věcná významnost

Pod 5\% - nízká (sociologicky neprokazatelná)

5-9,9\% - střední (sociologicky prokazatelná)

Nad $10 \%$ - výrazná

Pro názornost připojuji použitou otázku a možnosti výběru odpovědí:

Jak ovlivnili následující osoby a instituce váš vztah ke sportu?

a) Rodina (rodiče, staří rodiče, sourozenci)

b) škola (celkové klima a systém)

atd.

K posouzení použijte stupnici s negativní vzestupnou tendencí směrem od 3 až po 1 , se středem 4 (nijak neovlivnili) a pozitivní vzestupnou tendencí směrem od 5 až po 7.

1 - max. negativně

1
4 - neovlivnil

2

34

5 7-max. pozitivně

$6 \quad 7$ 


\section{VÝSLEDKY}

\section{A.Výsledky pilotní studie}

Test - retest provedlo 53 studentů vyšších ročníků s opakováním po $1-2$ týdnech, tak aby se již snížil efekt zapamatování původních odpovědí, a ještě nedošlo ke změně zkoumaných indikátorů (Malý, 2000).

Tabulka č. 1: Test - retest pilotní studie (Test reliability)

\begin{tabular}{|c|c|c|}
\hline Otázka č. & Indikátor & Spearman. k.k. \\
\hline 1 & Rodina (rodiče, staří rodiče, sourozenci) & 0,768 \\
\hline 2 & Škola (celkové klima a systém) & 0,630 \\
\hline 3 & Dění v místě bydliště (sport.klub, akce) & 0,752 \\
\hline 4 & Média (TV, rádio, noviny) & 0,478 \\
\hline 5 & Úspěch našich reprezentantů & 0,628 \\
\hline 6 & Kamarádi, spolužáci & 0,524 \\
\hline 7 & Učitel TV na ZŠ & 0,824 \\
\hline 8 & Učitel TV na SŠ & 0,821 \\
\hline 9 & Učitel TV na V̌̌ & 0,704 \\
\hline 10 & Partner & 0,561 \\
\hline 11 & Sportovní vzor & 0,850 \\
\hline
\end{tabular}

Podle tzv. interpretace souvislostí podle korelačního koeficientu (De Vaus, 2002) prošly testem reliability všechny indikátory. Většina $\mathrm{z}$ použitých indikátorů se vešla do kategorie interpretace souvislostí „podstatné až velmi silné“ $(0,50-0,69)$ nebo do kategorie „velmi silné“ $(0,70-0,89)$.

\section{B. Hlavní výzkum}

Všechny výsledky zjištěné pomocí statistického programového systému SPSS verze 14.0 jsou uvedeny v následujících tabulkách.

Tabulka č. 2 - pořadí jednotlivých indikátorů při ovlivňování ke sportu u chlapců a dívek

\begin{tabular}{|c|c|c|c|c|c|c|c|}
\hline \multirow{2}{*}{ Indikátor } & \multicolumn{2}{|c|}{ Chlapci } & \multicolumn{2}{c|}{ Dívky } & \multicolumn{2}{c|}{ Rozdíl } & \multicolumn{2}{c|}{ Pořadí indik. } \\
\cline { 2 - 7 } & Průměr & Std & Průměr & Std. & průměrů & Chlapci & Dívky \\
\hline Kamarádi, spolužáci & 5,37 & 1,01 & 5,26 & 0,99 & 0,11 & 1. & 2. \\
\hline Rodina, sourozenci & 5,15 & 1,25 & 5,34 & 1,29 & $-0,19$ & 2. & 1. \\
\hline Učitel TV na VŠ & 4,79 & 1,02 & 4,97 & 1,11 & $-0,18$ & 3. & 4. \\
\hline Sp. činnost v bydlišti & 4,69 & 1,21 & 4,68 & 1,25 & 0,01 & 4. & 5. \\
\hline Škola (klima, systém) & 4,54 & 1,21 & 4,37 & 1,44 & 0,17 & 5. & 6. \\
\hline Sportovní vzor & 4,53 & 0,98 & 4,35 & 0,86 & 0,18 & 6. & 7. \\
\hline Partner & 4,47 & 1,04 & 5,16 & 1,27 & $-0,69$ & 7. & 3. \\
\hline Média & 4,33 & 0,87 & 4,24 & 0,75 & 0,09 & 8. & 8. \\
\hline Učitel TV na SŠ & 4,31 & 1,23 & 4,04 & 1,47 & 0,27 & 9. & 10. \\
\hline Naši reprezentanti & 4,30 & 0,85 & 4,21 & 0,71 & 0,09 & 10. & 9. \\
\hline Učitel TV na ZŠ & 4,10 & 1,24 & 3,90 & 1,30 & 0,20 & 11. & 11. \\
\hline Průměr všech indikátorů & 4,60 & & 4,59 & & 0,06 & & \\
\hline
\end{tabular}


Tabulka č. 3 - věcná významnost rozdílů v jednotlivých indikátorech mezi chlapci a děvčaty

\begin{tabular}{|c|c|c|c|c|c|c|}
\hline \multirow{2}{*}{ Vědecký indikátor } & \multicolumn{2}{|c|}{ Chlapci } & \multicolumn{2}{c|}{ Dívky } & \multirow{2}{*}{$\begin{array}{c}\text { Rozdíl } \\
\text { Me }(\%)\end{array}$} & $\begin{array}{c}\text { Věcná } \\
\text { významnost }\end{array}$ \\
\cline { 2 - 5 } & Kat. & Me (\%) & Kat. & Me (\%) & Výrazná \\
\hline Partner & 4 & 68,2 & 4 & 41,2 & $-27,0$ & Výrazná \\
\hline Sportovní vzor & 4 & 69,5 & 4 & 81,4 & 11,9 & Vy̌rední \\
\hline Naši reprezentanti & 4 & 76,3 & 4 & 85,0 & 8,7 & Střednín \\
\hline Média & 4 & 70,3 & 4 & 77,0 & 6,7 & Střednín \\
\hline Učitel TV na VŠ & 5 & 76,3 & 5 & 69,7 & $-6,6$ & Střední \\
\hline Rodina, sourozenci & 5 & 59,1 & 5 & 52,9 & $-6,2$ & Střední \\
\hline Učitel TV na ZŠ & 4 & 73,1 & 4 & 78,8 & 5,7 & Střední \\
\hline Učitel TV na SŠ & 4 & 62,5 & 4 & 67,9 & 5,4 & Střední \\
\hline Kamarádi, spolužáci & 5 & 56,4 & 5 & 59,1 & 2,7 & Nízká \\
\hline Sp. činnost v bydlišti & 4 & 53,0 & 4 & 55,5 & 2,5 & Nízká \\
\hline Škola (klima, systém) & 5 & 80,3 & 5 & 81,4 & 1,1 & Nízká \\
\hline
\end{tabular}

\section{Vysvětlivky ke zkratkám v tabulkách:}

Průměr - index, který představuje vážený aritmetický průměr a pohybuje se v rozmezí 1-7 (Sak a Saková, 2004).

Std. - směrodatná odchylka

Kat. - pořadí kategorie na 7bodové Likertově škále, ve které je obsaženo 50 \% všech údajů, jestliže sčítáme postupně od první kategorie výše (Šlik, 2000).

Me - mediánová kategorie (Šlik, 2000; Řezanková, 2007)

- (minus) u Rozdílu Me znamená, že děvčata mají vyšší hodnoty než chlapci

\section{DISKUSE}

\section{A. Vliv jednotlivých osob a institucí na sportování mládeže podle výsledků \\ Chlapci}

Z tabulky je patrné, že v životě studentů ČVUT představuje nejsilnější impuls ke sportování parta, tj. spolužáci a kamarádi. 3 negativní kategorie u tohoto indikátoru označilo jen 5,1\% chlapců; 24,8 \% studentů neovlivnili kamarádi nijak a celkem $70 \%$ chlapců označilo 3 kladné kategorie, z toho ještě $1 / 4 \mathrm{z}$ nich označila vliv kamarádů jako maximální.

Velice silný, ale o něco menší vliv má na studenty široké rodinné zázemí (rodiče, prarodiče, sourozenci).

Zajímavou kapitolu tvoří učitelé tělesné výchovy na všech třech stupních školní výchovy.

Ačkoli by se mohlo zdát, že studenti si již své učitele na ZŠ a SŠ tolik nepamatují, opak je pravdou. Prvním důkazem je sám Spearmanův korelační koeficient v pilotní studii, který má hodnotu 0,82 u učitelů ZŠ a SŠ, 0,70 pak u učitelů na VŠ. (Při doplňujícím rozhovoru nám všichni otázaní studenti v počtu 23 odpověděli, že si přesně pamatují, kdo a jak je učil tělesnou výchovu na všech stupních škol). Na větší oblibu asistentů VŠ může mít vliv i to, že si zde studenti vybírají svůj sport ze široké nabídky různých sportovních odvětví.

Výsledky signalizují, že nejvíce studenty ovlivňují učitelé TV na vysoké škole (3. místo ze všech indikátorů), méně pak na střední škole a nejméně na základní škole. Na druhou stranu je skoro zarážející až poslední místo učitelů TV na základní škole ze všech indikátorů při nasměrování žáků ke sportování (17,5\% studentů označilo 3 negativní kategorie; 55,5\% učitel TV neovlivnil nijak; a jen $27 \%$ studentů ovlivnil kladně, z toho $4,3 \%$ maximálně).

Je nutno zde připomenout i předepsané plnění školních osnov včetně známkování gymnastických či atletických výkonů, které u některých dětí nepřidává na sympatiích $\mathrm{k}$ TV. 
Odpovědi studentů tak charakterizují negativní skutečnost. V době mladšího a stř̌edního školního věku, kdy se dají děti nejvíce ovlivnit a získat tak kladnou potřebu k pohybu pro celý život, se to jejich učitelům nedaří.

I když učitelé TV na střední a základní škole nejspíše nedělají svou práci úplně tak, jak bychom si představovali, celkové klima a systém vedoucí ke sportování ve školách i v místě bydliště studentů je nastaveno poměrně kladně (4. a 5. místo mezi všemi indikátory). Chlapce kladně ovlivňují i sportovní vzory, o něco méně pak v současnosti jejich partnerky.

Od partnerek by se možná očekával př́íznivější vliv, podstata problému také nejspíše spadá do zjištěného faktu, že 47,8\% chlapců našeho souboru ještě nenavázalo partnerský vztah. Také je známo, že ženy se věnují sportu všeobecně méně než muži.

Vedle již jmenovaných učitelů TV na střední a základní škole mají sice ještě kladný, ale ne př́liš patrný vliv na sportování mládeže média a naši reprezentanti.

\section{Dívky}

U dívek je vliv jednotlivých indikátorů dosti podobný, ne však úplně stejný. Nejsilnější impulz pro sportování dostávají děvčata ze svého širokého rodinného zázemí. 3 negativní kategorie u tohoto indikátoru označilo jen $5,1 \%$ děvčat; $24,8 \%$ studentek rodina neovlivnila nijak a celkem $70,1 \%$ děvčat označilo 3 kladné kategorie, z toho ještě čtvrtina z nich označila vliv rodiny jako maximální. Spolužáci (-kyně) a kamarádi (-ky) vytváří druhý největší tlak na sportování dívek, je jen o málo menší než vliv rodiny.

Trochu překvapivé se může zdát třetí místo, které zaujali partneři našich studentek. Je třeba podotknout, že oproti chlapcům žije v partnerském svazku daleko více studentek ČVUT, a to u našeho souboru celkem 73,6\%. Podobně silně kladně ovlivňují studentky také učitelé TV na ČVUT. V dalších indikátorech děvčata vykazují podobné názory jako chlapci.

Opět poslední místo zaujali učitelé (učitelky) TV na základní škole, když 3 negativní kategorie u tohoto indikátoru označilo až 20,4\% děvčat (z toho 8,4\% maximálně negativně); $58,4 \%$ studentek učitelé TV na ZŠ neovlivnili nijak a pouze $21,2 \%$ děvčat označilo 3 kladné kategorie, z toho jen 3,3\% z nich označila vliv učitelů TV na ZŠ jako maximální. Jako jediný z měřených indikátorů se propadli učitelé a učitelky TV na základní škole do minusových čísel.

Rozmanitost použité metodiky v různých studiích zahraničních i domácích autorů (Sigmund et al., 2008) je hlavním problémem při komparaci výsledků mé studie s ostatními. Obecně však mohu konstatovat, že mé výsledky se vcelku shodují s jinými výzkumy, i když prováděnými u mladší mládeže. Např. při srovnání výsledků mého souboru s výsledky Seabry et al. (2008) na vzorku 3352 chlapců a děvčat ve věku 10-18 let zjištuji, že vliv rodičů, kamarádů a učitelů TV je víceméně stejný.

U portugalské mládeže tvoří rodina ještě největší výchovný element vzhledem k ovlivnění ke sportu (matka $79 \%$, otec $73 \%$, sourozenci $72 \%$ ); vrstevníci ovlivňují v $73 \%$ případů a učitelé TV v $63 \%$ případů.

\section{B. Porovnání rozdílů mezi poskytnutými údaji od chlapců a děvčat}

Podle předem stanovených kritérií ve smyslu tzv. „věcné významnosti“ je z tabulky č. 3 možno dedukovat určité soudy. $\mathrm{Na}$ většinu indikátorů odpověděli chlapci a děvčata rozdílně. Při vzájemném porovnání poskytnutých názorů jsem zaznamenal největší rozdíl př̀i hledání vlivu na sportování u indikátoru „partner (ka)“, kde byla nalezena „výrazná věcná významnost“ (-27 \%). Tento údaj svědčí o tom, že děvčata daleko více ovlivňují při výběru činnosti volného času jejich partneři, kteří provádějí určitou pohybovou činnost. S děvčaty a chlapci to je v těchto partnerských vztazích konkrétně tak, že 3 negativní kategorie u tohoto indikátoru označilo pouze $2,6 \%$ děvčat (oproti $6,0 \%$ chlapců); $26,4 \%$ děvčat nežije v partnerském vztahu (oproti 47,8\% chlapců); $12,3 \%$ děvčat jejich partner ke sportu nemotivuje vůbec (oproti $14,4 \%$ př́padů u chlapců); celkem $58,8 \%$ studentek označilo 3 kladné kategorie (oproti 31,8 chlapců), a z toho ještě $21,2 \%$ z nich označilo vliv svých partnerů za maximální (oproti $6,2 \%$ partnerek chlapců). Jak je vidět z údajů, rozdíl je opravdu veliký. Možná trochu nadsazeně z toho lze také vyčíst, že studentky ČVUT si za své partnery ve velkém počtu př́ipadů vybírají chlapce-sportovce. 
Druhou „výraznou věcnou významnost“ jsem nalezl u sportovního vzoru, kde chlapci předčili děvčata o $11,9 \%$.

U dalších pěti indikátorů byla objevena „střední věcná významnost“ v rozmezí 8,7-5,4\%. Naši reprezentanti (o 8,7 \%), média (6,7 \%), učitel TV na základní škole (5,7\%) a učitel TV na střední škole $(5,4 \%)$ více ovlivnili chlapce; učitelé TV na vysoké škole $(-6,6)$ a široká rodina $(-6,2 \%)$ pak zase více děvčata.

Např. sportovní reprezentanti ČR negativně motivovali ke sportu 3,0 \% chlapců, nijak 73,4\% studentů a kladně pak 23,7\% (resp. děvčata 2,2 - 82,8 - 15,0\%).

Z pozice našeho zaměstnání je zajímavý také výsledek u motivace ke sportu asistenty TV na vysoké škole. Zde děvčata a posléze i chlapci vyjadřují své názory takto:

Asistenti(ky) negativně motivovali ke sportu 1,5\% dívek, nijak nemotivovali 42,3\% studentek a kladně pak 56,2 \%, když z toho ještě 12,8 \% dívek maximálně kladně (resp. u chlapců 1,6 - 47,6 -50,8 - 7,3\%). Osobně si to vysvětluji především tím, že dívky přicházejí na vysokou školu s menší zkušeností a s menším počtem poznatků o sportu, a díky tomu jsou pro nás více „polem neoraným“. Při nabídce 37 sportovních odvětví pro tělesnou výchovu na Ústavu tělesné výchovy a sportu ČVUT je pak možné se většině dívek trefit do svých osobních preferencí při výběru sportu. Je dosti pravděpodobné, že některý ze sportů si dívky vyzkoušely poprvé v životě, oblíbily si jej, a toto poznání si odnášejí i do svého osobního života. Je také možné, že celkový spíše kamarádský postoj učitelů při výuce TV na VŠ spolu s určitou volností je balzámem na pošramocenou duši z tělesné výchovy na školách nižšího typu. I z toho vyplývá, že chlapce učitelé TV na základní škole (o 5,7\%) a učitelé TV na střední škole (o 5,4\%) přece jen motivovali o něco více než děvčata.

Naopak rodina (rodiče, staří rodiče, sourozenci) více přivádí ke sportu děvčata než chlapce $(-6,2 \%)$. Z pozice dívek vypadá porovnání s chlapci následovně: 3 negativní kategorie u tohoto indikátoru označilo o 1,9\% dívek méně; neovlivnění vůbec (-1,8 \%); 3 kladné kategorie (3,7 \%).

U indikátorů „kamarádi, spolužáci“; „sportovní činnost v místě bydliště“ a „škola“ nebyl nalezen ve vztahu chlapci-děvčata významný rozdíl.

\section{ZÁVĚRY}

Vybrané indikátory se podílí na výchově mládeže ve smyslu kladného ovlivnění ke sportovní činnosti rozdílnou měrou.

U chlapců se o to nejvíce přičiňují kamarádi a spolužáci (průměr na 7 bodové Likertově škále 5,37), těsně sledováni rodinou $(5,15)$ a také učitelé tělesné výchovy na vysoké škole $(4,79)$. Nejméně na ně v tomto smyslu výchovně působí učitelé TV na SŠ $(4,31)$, naši sportovní reprezentanti $(4,30)$ a učitelé TV na ZŠ $(4,10)$.

Na děvčata má největší kladný vliv jejich rodina $(5,34)$, kamarádky a spolužačky $(5,26)$ a také jejich partneři $(5,16)$. Nejmenší měrou se na utváření kladného vztahu ke sportu podílí naši reprezentanti $(4,21)$, učitelé TV na SŠ $(4,04)$ a učitelé TV na ZŠ $(3,90)$.

Největší rozdíly mezi studenty a studentkami byly na základě „věcné významnosti“ shledány jako „výrazné“, a to při ovlivnění ke sportu od partnerů dívek či partnerek chlapců (27\% ve prospěch dívek) a od sportovních vzorů (11,9 ve prospěch chlapců).

„Stř̌ední věcná významnost“ byla analyzována u těchto indikátorů (z pohledu chlapců): naši reprezentanti $(8,7 \%)$, média $(6,7 \%)$, učitel TV na VŠ $(-6,6 \%)$, rodina $(-6,2 \%)$, učitel TV na ZŠ $(5,7 \%)$ a učitel TV na SŠ (5,4 \%).

\section{Literatura}

BARANOWSKI, T., BOUCHARD, C., BAR-OR, O., BRICKER, T., HEATH, G., KIMEZ, SY, MALINA, R., OBARZANEK, E., PATE, R. \& STRONG, WB. (1992). Assessment, prevalence and cardiovascular benefits of physical activity and fitness in youth. Medicine and Science in Sport \& Exercise, 24 (6): 237-247. BAXTER-JONES, ADG., MAFFULI, N. (2003) Parental influence on sport participation in elite young athletes. The Journal of sports medicine and physical fitness, 43 (2):250-255. 
BLAHUŠ, P. (2000). Statistická významnost proti vědecké průkaznosti výsledků výzkumů.

Česká kinantropologie., 4 (2), 53-71.

BLAIKIE, N. (2003). Analyzing Quantitative Data. London: Sage. ISBN 0761967591.

BOUCHARD, C., SHEPARD, RJ., STEPHENS, T. et al. (1988). Exercise, fitness and health: the consensus statement. (eds), Exercise, Fitness and Health. Human Kinetics, Chicago, IL.

BOURDIEU, P. (1978). Sport and Social Class. Social Science Information, 17 (6): 819-840.

BRODERSEN, NH., STEPTOE, A., BONIFACE, DR. \& WARDLE, J. (2007). Trends in physical activity and sedentary behaviour in Adolescence: ethnic and socioeconomic differences. Br J Sports Med. 41: $140-144$.

BROCKMAN, R., JAGO, R., FOX, KR., THOMPSON, JL., CARTWRIGHT, K. \& PAGE, AS. (2009). „Get off the sofa and go and play": Family and socioeconomic influences on the physical activity of 10-11 year old children. BMC Public Health, 2009 (9): 253. Retrieved September 14, 2009, from http://www.biomedcentral.com/1471-2458/9/253

BROWN, B. (1985). Factors influencing the process of withdrawal by female adolescents from the role of the competitive age group swimmer. Sociology of Sport Journal, Seventh Annual Meeting.

BUNC, V. (2008). Aktivní životní styl mládeže jako determinant jejich zdatnosti a tělesného

složení. Studia Kinanthropologica, 9 (1): 19-23.

COAKLEY, J. (1987). Children and the Sport Socialization Process. In: Advances in Pediatric Sport Science. New York: Mc Graw-Hill. ISBN 0-07-056959-2.

COAKLEY, J. (2001). Sport in Society. New York: Mc Graw-Hill. ISBN 0-07-118155-5.

COLLINS, M. (2004). Sport, physical activity and social exlusion. Journal of Sports Sciences, 22: 727-740.

DAVISON, KK., CUTTING, TM. \& BIRCH, LL. (2003). Parents' activity-related parenting practices predict girls' physical activity. Med Sci Sports Exerc, 35 (9):1589-95.

DAVISON, KK., SCHMALZ, DL. (2006). Youth at risk of physical inactivity may benefit more from activity-related support than youth not at risk. Int J Behav Nutr Phys Act, 2006 (3): 5.

DAVISON, KK., JAGO, R. (2009). Change in Parent and Peer Support across Ages 9 to $15 \mathrm{yr}$ and Adolescent Girls' Physical Activity. Medicine \& Science in Sports \& Exercise, 41 (9): 1816-1825.

DE VAUS, D. (2002). Surveys in social research. London : Routledge. ISBN 0761973389.

DISHMAN, RK., SALLIS, JF. \& ORENSTIEN, DR. (1985). The determinants of physical activity and exercise. Public Health Report, 100: 158-171.

FERRON, C., NARRING, F., NARRING, M., CAUDERAY, M., et al. (1999). Sport activity in adolescence: associations with health perceptions and experimental behaviours. Health Education Research, 14 (2): 225-233.

FLEMR, L., VALJENT, Z. (2010). Socializace sportem. Studia sportiva. V tisku.

GREENDORFER, SL. \& EWING, ME. (1981). Race and gender differences in children's socialization into sport. Research Quarterly, 52: 301-310.

GREENDORFER, SL. (1992). Sport socialization. In T.S. Horn (Eds.), Advances in sport psychology (pp. 201-218). Champaign: Human Kinetics.

HNILICOVÁ, H. (2004). Dopad společenských změn po roce 1989 na kvalitu života lidí v ČR. In Hnilicová, H., (Eds.). Kvalita života, Sborník příspěvků z konference konané 25.10.2004 v Třeboni. ISBN 80-86625-20-6.

HOGG, M. \& ABRAMS, D. (1988). Social Identifications: A Social Psychology of Intergroup Relations. London: Routlenge.

CHRÁSKA, M. (2007). Metody pedagogického výzkumu. Praha: Grada publishing.

ISBN 978-80-247-1369-4.

JAGO, R., BROCKMAN, R., FOX, KR., CARTWRIGHT, K., PAGE, AS. \& THOMPSON, JL. (2009). Friendship groups and physical activity: qualitative findings on how physical activity is initiated and maintained among 10-11 year old children. The International Journal of Behavioral Nutrition and Physical Activity, Retrieved May 18, 2009, from http://www.encyclopedia.com/doc/1G1-192606757.html 
JANSA, P., KOCOUREK, J., VOTRUBA, J. \& DAŠKOVÁ, B. (2005). Sport a pohybové aktivity v životě české populace. Praha: UK FTVS.

KOIVULA, N. (2000). Children's gender-typing of physical activities and their parents' stereotyped expectations of feminity and masculinity. Aktuell beteendevetenskaplig idrottsforskning. Svebi:S Årsbok. Pp.103-112.

KOUKAL, J. (1996) Úloha asociace školních sportovních klubů ČR v rozvoji sportu na základních a středních školách. In: Tělesná výchova a sport na základních a středních školách. Brno: PedF MU.

KREMER, J. \& SCULLY, D. (1998). Psychology in Sport. Hove: Psychology Press Ltd.

LAUŠMAN, R. (1992). Příspěvek k metodě kauzálního modelování a její aplikaci v tělesné výchově a sportu. Disertační práce. Praha: UK FTVS.

LAWSHE, CH. (1975). A quantitative approach to content validity. Personel Psychology,

$28,563-575$.

LEWKO, JH. \& GREENDORFER, SL. (1988). Family influences in sport socialization of children and adolescents. In Smoll, FL., Magili, RA. \& Ash, MJ. (eds.) Children in Sport, 3rd ed., Champaign, IL: Human Kinetics.

MALÝ, M. (2000). Dotazníky o kvalitě života. Robust. s. 176-183. ISBN - 80-7015-792-5

Retrieved June 14, 2009 from http://www.statspol.cz/robust/2000_maly__00.pdf

MCGINNIS, L., CHUNHUN, S. \& MCQUILLAN, J. (2003). A review of gendered consumption in sport and leisure. Academy of Marketing Science Review, 5. Retrieved March 18, 2009, from www.vancouver. wsu.edu/otcgi/llscgi60

PATRIKSSON, G. (1994). Sport and physical activity as a socialisation environment (A scientific review). Göteborg: Council of Europe.

PECHA, O. (2005). K teorii postojů v kinantropologii. Česká kinantropologie, 9 (2), 61-75.

RYCHTECKÝ, A. (Eds.) (2006). Monitorování účasti mládeže ve sportu a pohybové aktivitě v České republice. Praha: UK FTVS.

ŘEHÁK, J. (1998) Quality of Data I. - Classical Model of Measuring Reliability and its Practical Application. Sociologický časopis, 34 (1), 51-60.

ŘEZANKOVÁ, H. (2007). Analýza dat $z$ dotazníkových šetření. Př́íbram: PBtisk.

ISBN 978-80-86946-49-8.

SAK, P. (2000). Proměny české mládeže. Praha: Petrklíč, 2000. ISBN: 80-7229-042-8

SAK, P., SAKOVÁ, K.(2004). Mládež na křižovatce. Praha: Svoboda Servis. ISBN 80-86320-33-2.

SALLIS, JF., ALCARAZ, JE., MCKENZIE, TL., HOWEL, MF., KOLODY, B. \& NADER, PR. (1992).

Parental Behavior in Relation to Physical Activity and Fitness in 9-Year-Old Children. American Journal of Diseas of Children, 146: 1383-1388.

SALLIS, JF., \& OWEN, N. (1999). Physical Activity \& Behavioral Medicine. Thousand Oaks, London: SAGE.

SEABRA, AF., MENDONCA, DM., THOMIS, MA., PETERS, TJ. \& MAIA, JA. (2008). Associations between sport participation, demographic and socio-cultural factors in Portuguese children and adolescents. European journal of public health,18(1):25-30.

SEEFELDT, V., EWING, M., \& WALK, S. (1992). Overview of youth sports programs in the

United States. Washington, DC: Carnegie Council on Adolescent Development.

SEKOT, A. (2003). Socializace sportem - nezastupitelná součást výchovného procesu. 11. konference ČAPV - Sociální a kulturní souvislosti výchovy a vzdělávání. Retrieved July 19, 2009, from http://www. ped.muni.cz/CAPV11/4sekce/4_CAPV_Sekot.pdf

SEKOT, A. (2008). Sociologické problémy sportu. Praha: Grada. ISBN 978-80-247-2562-8.

SIGMUND, E., LOKVENCOVÂ, P., SIGMUNDOVÁ, D., TUROŇOVÁ, K. \& FROMEL, K. (2008). Vztahy mezi pohybovou aktivitou a inaktivitou rodičů a jejich 8-13letých dětí. Tělesná kultura,31(2): 89-101.

SKILLE, EA. (2005). Individuality or Cultural Reproduction?: Adolescents' Sport Participation in Norway: Alternative versus Conventional Sports. Internation Review of Sociology of Sport, 40 (3): 307-320. 
SOUKUP, P., RABUŠIC, L. (2007). Několik poznámek k jedné obsesi českých sociálních věd - statistické významnosti. Sociologický časopis/Czech Sociological Review, 43 (2), 378-395.

STAEMPFLI, MB. (2009). Reintroducing adventure into children's outdoor play environments. Environment and Behaviour, 41:268-280.

ŠLIK, L. (2000). Matematická statistika III. Retrieved November 29, 2008 from (http://web.quick.cz/libor. slik/doc/ms3.doc).

ŠPAČEK, O. (2008) Sociální diferenciace aktivní sportovní participace v České republice. In Věda v pohybu - pohyb ve vědě. Sborník př́spěvků. UK FTVS: Praha. ISBN 978-80-86317-59-5.

VALJENT, Z. (2008). Pokus o vymezení pojmu Aktivní životní styl. Česká kinantropologie, 12 (2): 42-50. WARDE, A. (2006). Cultural Capital and the Place of Sport. Cultural Trends, 15 (2/3): 107-22.

ZICH, F. (2005). Úvod do sociologického výzkumu. Praha: EUPRESS, ISBN 80-86754-19-7. 